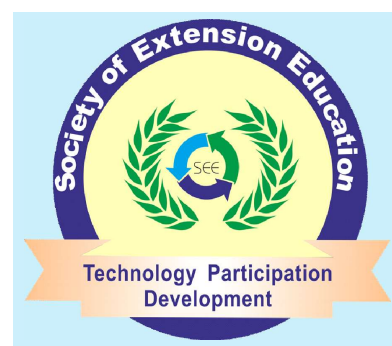

Research Article

\section{Indian Research Journal of Extension Education}

ISSN: 0972-2181 (Print), 0976-1071 (Online)

NAAS Rating : $\mathbf{5 . 2 2}$

Journal homepage: seea.org.in

https://doi.org/10.54986/irjee/2022/jan_mar/66-72

\title{
Information Sourcing and Managing Behavior of Dairy Entrepreneurs of Kerala
}

\author{
Shyam Suraj S.R. ${ }^{1}$ and K.S. Kadian ${ }^{2}$ \\ 1. Ph.D. Scholar, 2. Principal Scientist and Head, Dairy Extension Division, ICAR-National Dairy Research Institute, \\ Karnal, Haryana \\ Corresponding authore-mail : shyamsura@gmail.com
}

Paper Received on October 15, 2021, Accepted on December 20, 2021 and Published Online on January 01,2022

\begin{abstract}
The study was conducted in Kerala state to comprehend the information sourcing and managing behavior of dairy entrepreneurs; by examining the frequency of contact with the information sources, available sources of training, ICT utilization, market orientation and scientific orientation. The data was collected by survey using a structured schedule and the results were exhibited in tables. The overall frequency of contact was found to be medium for majority of the dairy entrepreneurs; the results exhibiting a similar trend also in market orientation. The preferred training centers by most of the entrepreneurs were dairy cooperatives due to their proximity and flexibility. The modern day information tools like android mobiles and television were the preferred ICT sources. Scientific orientation was higher for majority of the dairy entrepreneurs signifying an encouraging impact of the information management. The multiple linear regression model showed that while experience was negatively correlated; annual income, overall frequency of contact and market orientation were positively correlated and significant with scientific orientation. Among the three geographic regions, highland entrepreneurs had high scientific orientation. Nevertheless, overall results suggest the need for extension support and training interventions to improve the information sourcing and managing behavior of dairy entrepreneurs of the state.
\end{abstract}

Key words: Dairy; Entrepreneur; Information; Kerala; Sources; Regions

Kerala is the topmost literate state in India according to NSO Survey (GoI, 2020); and it has enabled the state to acquire better position with respect to various socioeconomic variables (Ohlan, 2012). The state ranks first in sustainable development index, human development index, overall health index and educational development index. The reflection of the same are expected to be visible similarly in agriculture and allied sectors; which prompts the farming community to efficiently gather required knowledge and use them to develop their enterprise. The present investigation was designed to understand the information sourcing and managing behavior of the dairy entrepreneurs of the state considering its high performance in dairy progressiveness index (Kale et al, 2016), dairy production systems index (Patel et al, 2019) and milk marketing infrastructure index (Mohapatra and Sendhil, 2020). These superior levels are attributed to the veterinary infrastructure (highest access of farmers to information on animal husbandry), animal breeding facilities (availability of semen production centers and AI services), resource availability 
(availability of natural resources like water, fodder etc.) and conducive policies and regulations (continued support of government in promoting dairying). As part of the study, variables included were the frequency of contact of the dairy entrepreneur with information sources, available sources of training, Information Communication Technology (ICT) utilization, market orientation; and scientific orientation, being a measure of information sourcing and managing behavior. Since scientific orientation is a result of effective information management, the study also looked into its relationship with the independent variables like age, gender, education, experience, herd size, annual income and relevant information sourcing and managing variables. The physiographical region-wise difference in scientific orientation of the dairy entrepreneurs were also analyzed.

\section{METHODOLOGY}

The study followed a survey research design using structured interview schedule following cross-sectional survey (Sivakumar et al, 2017). The respondents were dairy entrepreneurs operationally defined to have a minimum herd size of 4 cross bred dairy animals and selling 75 percent of the produced milk per day to the market throughout the year and the sold milk was not less than 10 liters per day. A sample of 240 dairy entrepreneurs, 80 each from the three physiographic divisions of highland, midland and lowland (CESS, 1984) were selected randomly from 4 blocks each of the three districts to collect data. The districts selected were Wayanad (highland), Ernakulam (midland) and Thiruvananthapuram (lowland).

Frequency of contact with information sources measured the exposure of respondents to different sources for obtaining information about dairy farming activities; scored by the respondents as 3, 2 and 1 for regular, occasional and never respectively. ICT utilization was destined to identify the frequency of use of ICT tools for obtaining information on different aspects of dairying. Market orientation was measured as the degree to which the respondent was oriented towards sale of milk and milk products as a major component of dairying activity, studied by modifying the scale developed by Samanta (1977). Scientific orientation was measured as the degree to which the dairy entrepreneur was oriented towards the use of scientific methods in dairy enterprise and was studied by modifying the scale developed by Supe (1969). For market and scientific orientation, statements were scored by respondents as 3,2 and 1 for agree, undecided and disagree. Training undergone in dairying collected information on the trainings attended by the entrepreneur during the previous year in different dairy training institutions and the total number of training days. The expected frequencies of the variables were classified into equal class intervals for frequency of contact with sources of information, scientific orientation and market orientation; whereas ICT utilization and trainings undergone were expressed using frequency and percentage. Multiple linear regression model was used to estimate the relationship between the scientific orientation of the dairy entrepreneurs and the independent variables including age, gender, years of education, experience, herd size, income, overall frequency of contact, number of training days, region and market orientation using STATA software.

\section{RESULTS AND DISCUSSION}

The results of the study were expressed in tables followed by explanation covering the details.

Frequency of contact with information sources: The information sources were classified into four categories - personal cosmopolite, personal localite, impersonal cosmopolite and miscellaneous sources. The frequency of contact scores of the dairy entrepreneurs to these different sources and the overall sources were separately tabulated as given below.

Personal cosmopolite sources: This included the frequency of contact of the dairy entrepreneur with veterinary surgeon, dairy department officials, dairy cooperative, training centers, university experts and private agencies. Majority of the entrepreneurs had medium level of contact with the personal cosmopolite sources in all the three regions (Table 1A); which can be attributed to the literacy and awareness level of the entrepreneurs. The results were in support to the findings by Singh et al (2021) in his study on the contact of dairy farmers with personal cosmopolite sources in Uttar Pradesh and Manjunath et al (2020) in terms of dairy farmer's extension contact in Karnataka.

Personal localite sources : The personal localite sources included family members, friends, neighbors, relatives, panchayat members and other dairy entrepreneurs. Majority of the entrepreneurs had 
Table 1. Distribution of respondents based on frequency of contact with information sources

\begin{tabular}{lllll}
\hline Categories & $\begin{array}{l}\text { Highland } \\
(\mathrm{n}=80)\end{array}$ & $\begin{array}{l}\text { Midland } \\
(\mathrm{n}=80)\end{array}$ & $\begin{array}{l}\text { Lowland } \\
(\mathrm{n}=80)\end{array}$ & $\begin{array}{l}\text { Total } \\
(\mathrm{n}=240)\end{array}$ \\
& No. $\%$ & No. $\%$ & No. \% & No. \% \\
\hline
\end{tabular}

\begin{tabular}{lllllllll}
\hline A. Contact & with & personal cosmopolite sources \\
High & 15 & 18.75 & 5 & 6.25 & 1 & 1.25 & 21 & 8.75 \\
Medium & 61 & 76.25 & 61 & 76.25 & 70 & 87.50 & 192 & 80.0 \\
Low & 4 & 5.00 & 14 & 17.50 & 9 & 11.25 & 27 & 11.25
\end{tabular}

B. Contact with personal localite sources

$\begin{array}{lllllllll}\text { High } & 37 & 46.25 & 29 & 36.25 & 19 & 23.75 & 85 & 35.40 \\ \text { Medium } & 40 & 50.00 & 46 & 57.50 & 46 & 57.50 & 132 & 55.00 \\ \text { Low } & 3 & 3.75 & 5 & 6.25 & 15 & 18.75 & 23 & 9.60\end{array}$

C. Impersonal cosmopolite sources

$\begin{array}{lllllllll}\text { High } & 22 & 27.50 & 19 & 23.75 & 13 & 16.25 & 54 & 22.50\end{array}$

$\begin{array}{lllllllll}\text { Medium } \quad 49 & 61.25 & 52 & 65.00 & 46 & 57.50 & 147 & 61.25\end{array}$

$\begin{array}{lllllllll}\text { Low } & 9 & 11.25 & 9 & 11.25 & 21 & 26.25 & 39 & 16.25\end{array}$

D. Miscellaneous sources

$\begin{array}{lllllllll}\text { High } & 20 & 25.00 & 18 & 22.50 & 9 & 11.25 & 47 & 19.58\end{array}$

$\begin{array}{lllllllll}\text { Medium } \quad 33 & 41.25 & 38 & 47.50 & 37 & 46.25 & 108 & 45.00\end{array}$

$\begin{array}{lllllllll}\text { Low } & 27 & 33.75 & 24 & 30.00 & 34 & 42.50 & 85 & 35.42\end{array}$

E. Overall frequency of contact

$\begin{array}{lllllllll}\text { High } & 3 & 3.75 & 6 & 7.50 & 1 & 1.25 & 10 & 4.20 \\ \text { Medium } & 73 & 91.25 & 67 & 83.50 & 56 & 70.00 & 196 & 77.90 \\ \text { Low } & 4 & 5.00 & 7 & 8.75 & 23 & 28.75 & 34 & 17.90\end{array}$

F. Sources of training

$\begin{array}{lllllllll}\text { DCS } & 38 & 47.50 & 38 & 47.50 & 28 & 35.00 & 104 & 43.30 \\ \text { DTC } & 3 & 3.75 & 0 & 0.00 & 14 & 17.50 & 17 & 7.00 \\ \text { MILMA } & 3 & 3.75 & 0 & 0.00 & 0 & 0.00 & 3 & 1.25 \\ \text { KVASU } & 9 & 11.25 & 1 & 1.25 & 0 & 0.00 & 10 & 4.17 \\ \text { AHD } & 4 & 5.00 & 8 & 10.00 & 3 & 3.75 & 15 & 6.25 \\ \text { KVK } & 1 & 1.25 & 0 & 0.00 & 0 & 0.00 & 1 & 0.40 \\ \text { NDRI } & 1 & 1.25 & 0 & 0.00 & 0 & 0.00 & 1 & 0.40 \\ \text { KLDB } & 1 & 1.25 & 1 & 1.25 & 0 & 0.00 & 2 & 0.80 \\ \text { KUD } & 1 & 1.25 & 2 & 2.50 & 0 & 0.00 & 3 & 1.25 \\ \text { DESU } & 4 & 5.00 & 0 & 0.00 & 2 & 2.50 & 6 & 2.50 \\ \text { NGO } & 0 & 0.00 & 2 & 2.50 & 0 & 0.00 & 2 & 0.80 \\ \text { Total } & 65 & 81.25 & 52 & 65.00 & 47 & 58.75 & 164 & 68.30\end{array}$

G. Market Orientation

\begin{tabular}{lllllllll} 
High & 21 & 26.25 & 48 & 60.00 & 30 & 37.50 & 99 & 41.25 \\
Medium & 44 & 55.00 & 28 & 35.00 & 38 & 47.50 & 110 & 45.85 \\
Low & 15 & 18.75 & 4 & 5.00 & 12 & 15.00 & 31 & 12.90 \\
H. Scientific & Orientation & & & & & & \\
High & 49 & 61.25 & 51 & 63.75 & 23 & 28.75 & 123 & 51.25 \\
Medium & 29 & 36.25 & 27 & 33.75 & 50 & 62.50 & 106 & 44.20 \\
Low & 2 & 2.50 & 2 & 2.50 & 7 & 8.75 & 11 & 4.55 \\
\hline
\end{tabular}

Score : High ( $>13)$; Medium (10-13); High $(<10)$

DCS - Dairy Cooperatives; DTC - Dairy Training Centre;
MILMA: Kerala Cooperative Milk Marketing Federation; KVASU - Kerala Veterinary and Animal Sciences University; AHD - Animal Husbandry Dept.; KVK - Krishi Vigyan Kendra; NDRI - National Dairy Research Institute; KLDB Kerala Livestock Development Board; KUD-Kudumbasree, DESU - Dairy Extension Service Unit; NGO - NonGovernmental Organizations

medium level of contact with personal localite sources. It was also seen that a reasonable number of dairy entrepreneurs had fairly high level too; especially in highland (46.25\%) owing to the rural settings, agrarian background and close knit community (Table 1B). The results coincided with the findings of Patil et al (2015) and Singh et al (2021).

Impersonal Cosmopolite: The sources included television, radio, newspaper, social media, books and magazines. Majority of the entrepreneurs were in the medium category; but it was worth noting that a fair number of entrepreneurs in the highland and midland had high contact with impersonal cosmopolite sources (Table 1C), attributed to the increase in use of television and social media by the farming entrepreneurs since last few decades (Thakur et al, 2017).

Miscellaneous sources: This included tour/field trips, exhibitions, off campus trainings, visit to research institutes and internet sources. Most of the entrepreneurs belonged to the medium category in the three regions. But a better share of the entrepreneurs in three regions were in the low contact category also, showing their disinterest in tours, exhibitions, visits to institutes and limited use of internet sources (Table 1D).

Overall frequency of contact : In the summation of the frequency of contact with all the four types of sources, majority of the dairy entrepreneurs fell in the medium category for all the three regions. The high and low level categories were comparatively small as given in Table $1 \mathrm{E}$.

Training in dairying: The highland entrepreneurs had attended more trainings during the year 2018-19 when compared with other two regions. Maximum attendees were for the trainings conducted by Dairy Cooperatives (DCS) as they were easily accessible to the entrepreneurs with flexible timings after their routine functions and restricted to a single day. A glance of Table 6 present that, there were enough sources available for training to the dairy entrepreneurs. The presence of Kerala Veterinary and Animal Sciences 
Table 2. Distribution of respondents based on ICT utilization

\begin{tabular}{|c|c|c|c|c|c|c|c|c|c|c|c|}
\hline \multirow{2}{*}{ Region } & \multirow{2}{*}{ Usage } & \multicolumn{2}{|c|}{ VideoPlayer } & \multicolumn{2}{|c|}{ AndroidMobile } & \multicolumn{2}{|c|}{ Computer/Laptop } & \multicolumn{2}{|c|}{ Television } & \multicolumn{2}{|c|}{ Radio } \\
\hline & & No. & $\%$ & No. & $\%$ & No. & $\%$ & No. & $\%$ & No. & $\%$ \\
\hline \multirow[t]{5}{*}{ Highland(n=80) } & Daily & 0 & 0.00 & 54 & 67.50 & 8 & 10.00 & 67 & 83.75 & 3 & 3.75 \\
\hline & Weekly & 1 & 1.25 & 5 & 6.25 & 2 & 2.50 & 1 & 1.25 & 2 & 2.50 \\
\hline & Monthly & 2 & 2.50 & 2 & 2.50 & 4 & 5.00 & 3 & 3.75 & 3 & 3.75 \\
\hline & Occasional & 5 & 6.25 & 0 & 0.00 & 1 & 1.25 & 1 & 1.25 & 4 & 5.00 \\
\hline & Never & 72 & 90.00 & 19 & 27.50 & 65 & 81.25 & 8 & 10.00 & 68 & 85.00 \\
\hline \multirow[t]{5}{*}{ Midland(n=80) } & Daily & 0 & 0.00 & 53 & 66.25 & 9 & 11.25 & 57 & 71.25 & 5 & 6.25 \\
\hline & Weekly & 0 & 0.00 & 6 & 7.50 & 4 & 5.00 & 4 & 5.00 & 2 & 2.50 \\
\hline & Monthly & 5 & 6.25 & 1 & 1.25 & 1 & 1.25 & 5 & 6.25 & 1 & 1.25 \\
\hline & Occasional & 4 & 5.00 & 0 & 0.00 & 1 & 1.25 & 7 & 8.75 & 1 & 1.25 \\
\hline & Never & 71 & 88.75 & 20 & 25.00 & 65 & 81.25 & 7 & 8.75 & 71 & 88.75 \\
\hline \multirow[t]{5}{*}{ Lowland(n=80) } & Daily & 0 & 0.00 & 39 & 48.75 & 3 & 3.75 & 61 & 76.5 & 2 & 2.50 \\
\hline & Weekly & 0 & 0.00 & 2 & 2.50 & 0 & 0.00 & 1 & 1.25 & 3 & 3.75 \\
\hline & Monthly & 3 & 3.75 & 5 & 6.25 & 3 & 3.75 & 4 & 5.00 & 6 & 7.50 \\
\hline & Occasional & 1 & 1.25 & 0 & 0.00 & 0 & 0.00 & 5 & 6.25 & 2 & 2.50 \\
\hline & Never & 76 & 95.00 & 34 & 42.50 & 74 & 92.50 & 9 & 11.25 & 67 & 83.75 \\
\hline \multirow[t]{5}{*}{$\operatorname{Total}(\mathrm{n}=240)$} & Daily & 0 & 0.00 & 146 & 60.83 & 20 & 8.33 & 185 & 77.08 & 10 & 4.17 \\
\hline & Weekly & 1 & 0.42 & 13 & 5.42 & 6 & 2.50 & 6 & 2.50 & 7 & 2.92 \\
\hline & Monthly & 10 & 4.17 & 8 & 3.33 & 8 & 3.33 & 12 & 5.00 & 10 & 4.17 \\
\hline & Occasional & 10 & 4.17 & 0 & 0.00 & 2 & 0.83 & 13 & 5.42 & 7 & 2.92 \\
\hline & Never & 219 & 91.25 & 73 & 30.42 & 204 & 85.00 & 24 & 10.00 & 206 & 85.82 \\
\hline
\end{tabular}

University (KVASU) in highland district (Wayanad) contributed to its nine trainings there; but they had less reach in other districts. The dairy entrepreneurs of lowland were found to be lesser interested in trainings; the same portrayed in their low adoption of technology and low investment in dairy farm assets.

ICT utilization: The use of information communication technology (ICT) was assessed and the results are given in Table 2. The use of video player, android mobile, computer/laptop, television and radio; and their usage pattern was studied. Among the ICT sources, android mobile and television were the habitually used ones by the dairy entrepreneurs in the three regions. This result coincides with the findings of Singh et al (2014) and Rathod et al (2016) in Indian context and Kafura et al (2016) in Bangladesh. The use of radio, video player and computer was very less in the three regions. Radio and video players had become old-fashioned in their relevance and use of computer may expedite in the future with more youngsters entering the dairy sector.

Market Orientation : Maximum entrepreneurs had medium market orientation in highland and lowland. But it was worthy to note that majority of midland entrepreneurs belonged to high level of market orientation (Table 1G). This was manifested from their higher milk production, higher local sales and distance travelled to effect local sales, which is linked to effective information management. The results agreed with the findings of George (2019) among women dairy farmers of Kerala and Ahuja et al (2016) among dairy farmers of Haryana.

Scientific Orientation: Higher scientific orientation was exhibited by the majority of entrepreneurs of highland and midland (61.25\% and $63.75 \%$ respectively); while majority were in medium category in the lowland (62.50\%) according to Table 9. Studies on entrepreneurial behavior of dairy farmers by Ahuja et al (2016) and Chaurasiya et al (2017) showed medium level of scientific orientation; contrary to the results of highland and midland entrepreneurs in the present study, but coinciding with the lowland results (Table 1H).

Multiple linear regression model : Multiple linear regression model to estimate the relationship between the scientific orientation of the dairy entrepreneurs and the independent variables is given in Table 3 .

The table showed that experience in dairying had negative and significant correlation with scientific orientation; signifying that nascent entrepreneurs were more scientifically oriented (better information sourcing and managing) than mature ones. Annual income, overall 
Table 3. Correlates of dairy entrepreneurs' scientific orientation (Multiple linear regression estimates)

\begin{tabular}{ll}
\hline $\begin{array}{l}\text { Dependent variable } \\
\text { Estimator }\end{array}$ & $\begin{array}{l}\text { Scientific Orientation } \\
\text { Ordinary Least Squares }\end{array}$ \\
\hline Age in years & $-0.02(0.03)$ \\
Years of education & $0.11(0.08)$ \\
Logarithm of experience & $-0.59^{* *}(0.24)$ \\
Dummy gender (takes value 1 for & \\
male and 0 for female) & $0.59(0.55)$ \\
Logarithm of herd size & $-0.29(0.68)$ \\
Logarithm of annual income & $2.23^{* * *}(0.55)$ \\
Overall frequency of contact & $0.26^{* * *}(0.05)$ \\
Days of training attended on dairying & $0.12(0.10)$ \\
Area (Base: Midland) & \\
Highland & $1.83^{* * *}(0.56)$ \\
Lowland & $-0.83(0.52)$ \\
Market Orientation & $0.26^{* * *}(0.042)$ \\
Constant term & $-24.6^{* * *}(6.11)$ \\
$\mathrm{N}$ & 240 \\
$\mathrm{R}^{2}$ & 0.62 \\
adj. R & 0.60 \\
$\mathrm{~F}$ & 47.5 \\
\hline
\end{tabular}

Note: Standard errors in parentheses $* * p<0.05, * * * p<0.01$
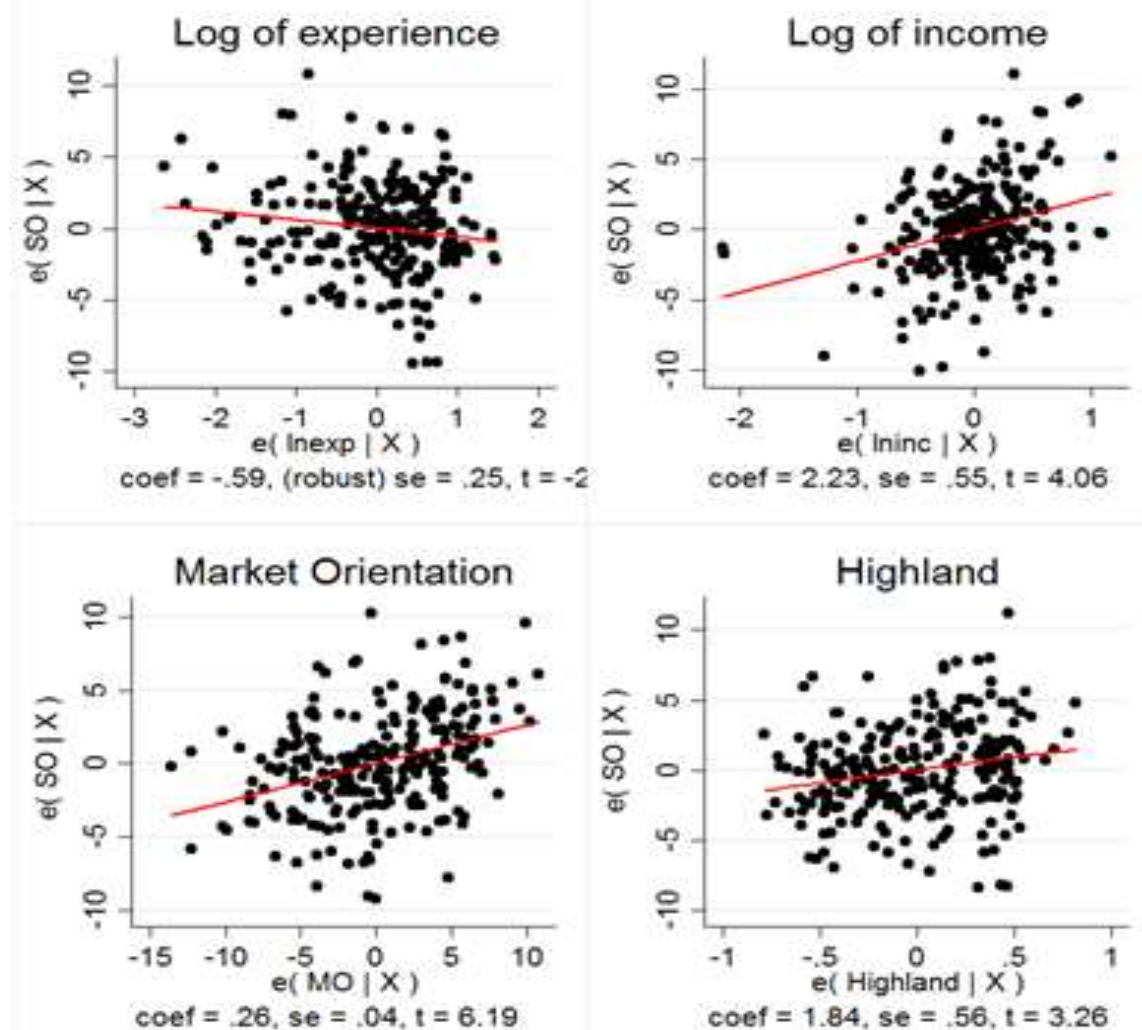

Fig 1. Significant correlates of dairy entrepreneurs' scientific orientation frequency of contact and market orientation were positive and significantly correlated. This illustrates that economic achievements from the enterprise urges an entrepreneur to gather additional information on scientific practices; which is gained through more contact with experts and orientation towards market. The results were in agreement with the findings of Anusha et al (2017) relating to the information managing behavior of rice farmers where extension contact and market orientation contributed to better scientific orientation. The significant correlations were visualized as given in the fig 1 . The region-wise difference in scientific orientation of the dairy entrepreneurs is given in fig. 2; which display highest significant levels $(p<0.01)$ for highland entrepreneurs and lowest for the lowland counterparts. The regression diagnostics is also follow.

\section{CONCLUSION}

The study concluded that the frequency of contact with the various source categories individually and in total were medium among majority of the dairy entrepreneurs. This revealed that the interest to contact the information sources were not highly developed among most of the dairy entrepreneurs, even when
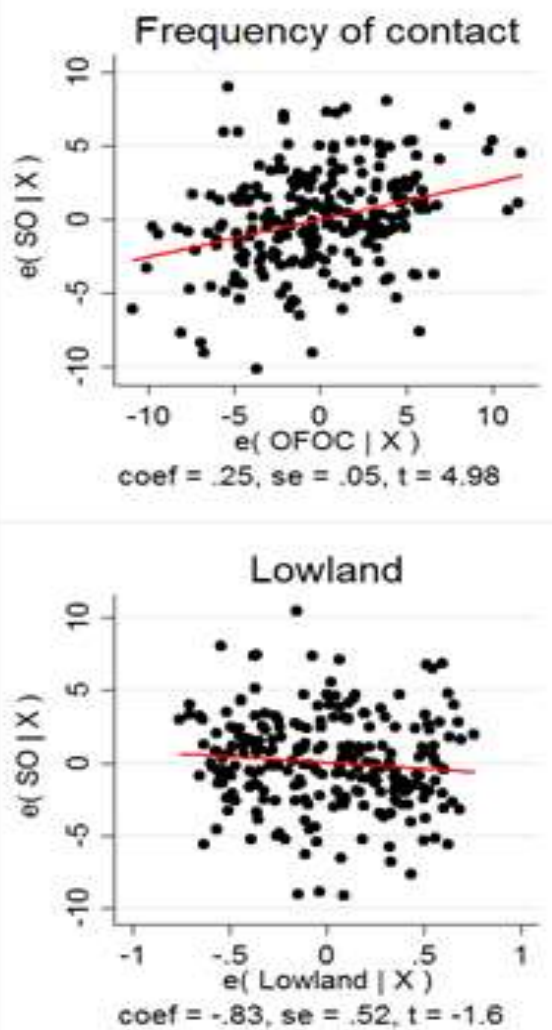


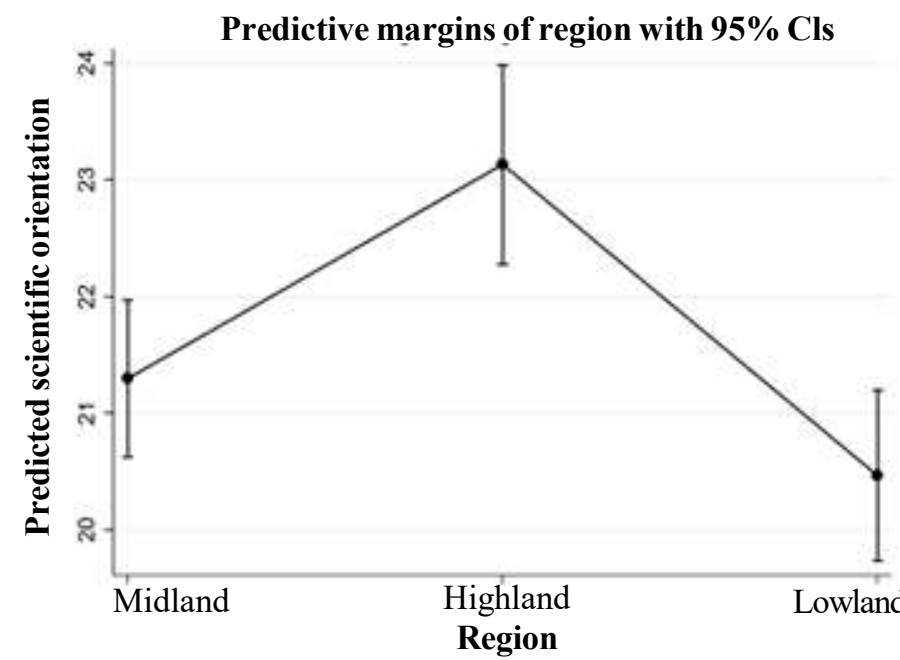

Fig 2. Region-wise scientific orientation of dairy entrepreneurs

Regression diagnostics

\begin{tabular}{|c|c|c|}
\hline Test & $\begin{array}{l}\text { Null } \\
\text { hypothesis }\end{array}$ & $\begin{array}{l}\text { Findings and } \\
\text { inference }\end{array}$ \\
\hline $\begin{array}{l}\text { Variance inflation } \\
\text { factor(VIF) for } \\
\text { multi-collinearity }\end{array}$ & $\begin{array}{l}\text { H0: No multi- } \\
\text { collinearity }\end{array}$ & $\begin{array}{l}\text { Mean VIF = } 1.71 \\
\text { No multi- } \\
\text { collinearity }\end{array}$ \\
\hline $\begin{array}{l}\text { Breusch-Pagan/ } \\
\text { Cook-Weisberg test } \\
\text { for heteroskedasticity }\end{array}$ & $\begin{array}{l}\text { H0: Constant } \\
\text { variance }\end{array}$ & $\begin{array}{l}\mathrm{P}=0.93 \\
\text { No heterosk- } \\
\text { edasticity }\end{array}$ \\
\hline Ramsey RESET test & $\begin{array}{l}\text { H0: model has } \\
\text { no omitted } \\
\text { variables }\end{array}$ & $\begin{array}{l}\mathrm{P}=0.11 \\
\text { No omitted } \\
\text { variables }\end{array}$ \\
\hline Link test & $\begin{array}{l}\mathrm{H} 0: \text { model is } \\
\text { correctly } \\
\text { specified }\end{array}$ & $\begin{array}{l}\text { No specification } \\
\text { error }\end{array}$ \\
\hline $\begin{array}{l}\text { Shapiro-Wilk } \\
\text { W test }\end{array}$ & $\begin{array}{l}\text { Ho: Error term } \\
\text { follows } \\
\text { normal } \\
\text { distribution }\end{array}$ & $\begin{array}{l}\mathrm{P}=0.24 \\
\text { Error term } \\
\text { follows normal } \\
\text { distribution. }\end{array}$ \\
\hline
\end{tabular}

availability was there. The results suggest expanding extension support and outreach by the dairy information sources in public, cooperative and private sector.
Highland entrepreneurs had attended more trainings when compared with other regions and irrespective of the region, maximum entrepreneurs participated in trainings conducted by dairy cooperatives. It showed that though there was good number of sources available for training in dairying, the entrepreneurs preferred the closer and flexible sources. This was an indication for training institutes to give extra thrust to off-campus trainings. Android mobile and television were the popular ICT sources and their use shall aid in the spread of upto-date information at a faster and efficient rate; while radio and video players were found to be obsolete. Majority of midland entrepreneurs had high market orientation than the other two regions owing to market opportunities available and the interest towards direct sales. The highland and lowland entrepreneurs required market information and training support to improve this attribute for better returns. Higher scientific orientation was exhibited by entrepreneurs of highland followed by midland; while majority were in medium category in the lowland. Lowland entrepreneurs needed adequate trainings to develop improved scientific attitude. Experience in dairying was significant but negatively correlated; and annual income, overall frequency of contact and market orientation were positively correlated with scientific orientation. The results in total expresses that, though the state has higher ranks in the dairy progressiveness, production systems and marketing infrastructure; the dairy information sourcing and managing behavior of dairy entrepreneurs needs improvement. This can be achieved though appropriate extension interventions and entrepreneurship trainings, which shall support the state to keep up its already held superior positions.

\section{CONFLICTS OF INTEREST}

The authors declare that they have no conflicts of interest.

\section{REFERENCES}

Ahuja, R., Singh, S.P., Sangwan, S.S. and Gautam. (2016). Entrepreneurial behavior of dairy farmers of Haryana. Haryana Vet, 55 (1): 6-11.

Anusha, A., Rambabu, P. and Gopikrishna, T. (2017). Information management behavior of rice farmers under collective farming in Kerala. J. Ext. Educ., 29 (3). 5885-5891.

CESS. (1984). Resource atlas of Kerala. Centre for Earth Science Studies. Thiruvananthapuram, Kerala.

Chaurasiya, K.K., Maratha, P. and Badodiya, S.K. (2017). Factors affecting entrepreneurial behavior of dairy farmers. Agri. Update, 12 (1): 23-30. 
George, R.P. (2019). Market orientation of women dairy farmers of Kerala. J. Ext. Educ., 31(4): 6405-6410.

GoI (2020). Household social consumption of education in India. NSS Report No. 585. Ministry of statistics and programme implementation office. National Statistics Office. New Delhi. 43.

Kafura, R.A., Afrad, M.D., Prodhan, F.A. and Chakraborthy, D.B. (2016). Use of ICT as extension tool by the farmers of Gazipur district in Bangladesh. Indian Res. J. Ext. Edu. 16 (2). 1-5.

Kale, R.B., Ponnusamy, K., Chakravarthy, A.K., Sendhil, R, and Mohammad, A. (2016). Assessing resource and infrastructure disparities to strengthen Indian dairy sector. Indian J. of Anim. Sci., 86 (6): 720-725.

Manjunath, M., Kumar, K.A., Kale, S.K., Barikar, U. and Sreenivas, B.V. (2020). Socio-economic profile analysis of dairy farmers of Yadgir district of Kalyana Karnataka region. J.of Pharm and Photo., 9 (4): 350-353.

Mohapatra, S. and Sendhil, R. (2020). Role of milk market infrastructure for sustainable dairy development. Indian J. Econ. Dev., 16 (SS): 402-407.

Ohlan, R. (2012). Pattern of regional disparities in socio-economic development in India: District Level Analysis. Soc. Indic. Res., 114 (3): 841-873.

Patil, S.D., Shinde, S.B., and Kharde, P.B. (2015). Communication mechanisms of farmer for acquisition of information on farm mechanization. Indian Res. J. Ext. Edu. 16 (1). 80-84.

Patel, D., Ponnusamy, K. and Sendhil, R. (2019). Development and testing of potential indicators for evaluation of dairy production systems. Indian J. of Ani. Sci., 89 (11) : 1274-1282.

Rathod, P.K., Chander, M. and Banger, Y. (2016). Use of mobiles in dairying for information dissemination: a multi-stakeholder analysis in India. Indian J. of Anim. Sci., 86 (3): 348-354.

Samantha, P.R. (1977). A study of some agro-climatic, socio-psychological and communication variable associated with repayment behavior of agricultural credit users of nationalized bank. Ph. D thesis. IARI. New Delhi.

Singh, A.K., Singh, A.K. and Maji, S. (2021). A study on socio-economic profile of the dairy farmers in central plain zone of Uttar Pradesh. Int. J. Curr. Microbiol. Appl. Sci., 10 (1): 988-995.

Singh, P., Tripathi, S.C. and Bardhan, D. (2014). Utilization pattern and perceived benefits of information communication technology (ICT) tools used by dairy farmers in Nainital district of Uttarakhand (India). Animal Sci. Reporter, 8 (4): 130139.

Sivakumar, P.S., Sontakki, B.S., Sulaiman, R.V., Saravanan, R. and Mittal, M. (2017). Manual on good practices in extension research and evaluation. AESA.12-15.

Supe, S. V. (1969). Factors related to different degree of rationality in decision making among farmers, Ph. D., Thesis (Unpublished), IARI, New Delhi.

Thakur, D., Chander, M. and Sinha, S.K. (2017). A scale to measure attitude of farmers towards social media use in agricultural extension. Indian Res. J. Ext. Edu. 17 (3). 10-15. 